\title{
Die Stellung der Studenten in der Universität
}

\author{
von \\ Professor Dr. Hans Heinrich Rupp \\ und \\ Professor Dr. Wilhelm Karl Geck
}

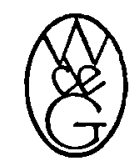

Berlin 1968

Walter de Gruyter \& Co.

vormals G. J. Göschen'sche Verlagshandlung / J. Guttentag, Verlagsbuchhandlung / Georg Relmer / Karl J. Trubner / Velt \& Comp. 
Archiv-Nr. 2759681

Satz und Druck: Druckerei Chmielorz GmbH, 1 Berlin 44 Alle Rechte, einschließlich des Rechtes der Herstellung von Fotokopien und Mikrofilmen, vorbehalten 